\title{
Behavioural and ecological aspects of black tufted-ear marmosets, Callithrix penicillata (Geoffroy, 1812) (Primates: Callitrichidae) in a semi- urban environment
}

\author{
MARINA NOGUEIRA DOS SANTOS ${ }^{1}$, MARINA HENRIQUES LAGE DUARTE ${ }^{1,2}$ \\ AND ROBERT JOHN YOUNG ${ }^{3}$
}

\begin{abstract}
O mico-estrela (Callithrix penicillata) é uma pequena espécie de primata neotropical que vive em vários tipos de ambientes como Cerrado e Mata Atlântica, podendo também ocupar áreas urbanas. Pesquisas já mostraram que a disponibilidade de recurso alimentar afeta a área de vida, o tamanho de grupo e o comportamento da espécie na natureza. Os objetivos deste estudo foram investigar o comportamento do mico-estrela em um ambiente urbanizado e a influência de recurso alimentar (estimado) na área de vida e na densidade populacional. O estudo foi realizado por meio de observações diretas (84 horas) com quatro grupos de mico-estrela vivendo nas dependências do zoológico de Belo Horizonte, Minas Gerais, Brasil. Os resultados mostraram que apesar de viverem em ambiente urbano, estes micos tem áreas de vida (2,85ha), tamanhos dos grupos (média=5,7 indivíduos) e densidades populacionais $(2,19$ ind/ha) parecidos com os valores obtidos para a espécie nativa. Os animais estudados, passaram a maior parte do dia se deslocando (22,45\%), descansando (16,58\%), inativos alertas (14,95\%) e alimentando-se (6,74\%). Estes resultados mostram que o padrão de atividade e o repertório comportamental exibidos pelos animais deste estudo são similares aos apresentados na natureza e portanto, evidenciam a capacidade de adaptação da espécie em ambientes antrópicos.
\end{abstract}

Palavras-chave: Urbanização; comportamento; mico-estrela; Callithrix penicillata; área de vida.

The black tufted-ear marmoset (Callithrix penicillata) is a small Neotropical primate, which lives in various types of environments from Cerrado (Brazilian savannah), Atlantic forest to urban areas. Research shows that food availability influences home range size, group size, population density and the behaviour of marmoset groups in the wild. The objective of this study was to investigate the behaviour of C. penicillata in an urbanized habitat, and the influence of (estimated) food availability on home range size, group size and population density. This study was performed through direct behavioural observation (84 hours) on four wild groups of marmosets living within the grounds of Belo Horizonte Zoological garden, Minas Gerais, Brazil. The results show that, despite living in an urban habitat, these marmosets presented home range size (2.85ha), group size (mean=5.7 ind.) and population density (2.19 ind/ha) values in the range found in wild-living conspecifics. The animals studied spent a considerable percentage of their time travelling (22.45\%); resting (16.58\%), inactive alert (14.95\%) and feeding (6.74\%). These results showed that behavioural activity repertoires were also found to be similar to wild-living conspecifics and therefore demonstrate the species adaptation capacity in urban environment.

Keywords. Urbanization; behaviour; marmosets; Callithrix penicillata; home range.

\footnotetext{
* Corresponding author: Marina Henriques Lage Duarte. Laboratório de Bioacústica, Museu de Ciências Naturais PUC Minas. Avenida Dom José Gaspar, 290, Bairro Coração Eucarístico, Campus PUC Minas, CEP: 30535-901, Belo Horizonte, Minas Gerais. Telephone: +55-31-3319-4058 E-mail: marinabioacustica@hotmail.com

1 Conservation, Ecology and Animal Behavior group, Bioacoustics Laboratory, Post-Graduate program in Vertebrate Zoology, PUC Minas, Brazil.

2 Laboratory of Ornithology, Department of Zoology, Federal University of Minas Gerais, Brazil.

3 School of Environment \& Life Sciences Peel Building Salford, University of Salford Manchester, England.
} 


\section{Introduction}

The black tufted-ear marmoset (Callithrix penicillata Geoffroy, 1812) is a small Neotropical primate (350 to $500 \mathrm{~g}$ ), whose original habitat is in the Cerrado areas (i.e. savannah) of central Brazil (Fonseca \& Lacher, 1984). In addition to it living in these natural habitats, it is a species that can be widely found in the parks and streets of the cities of Brazil (Leite et al., 2011).

Urbanization causes a reduction in natural habitats, which may result in the local extinction of species (Sabbatini et al., 2006). However, behaviourally flexible species can adapt to urban areas, where in some cases, they can easily find available food resources, such as garbage (Box, 1991). Urban primates, in particular, often directly compete with humans. One of the consequences of this is that some primate species are suffering changes in their behaviour, losing their fear of and, sometimes, becoming aggressive towards humans (Sabbatini et al., 2006). Due to its adaptability, learning and exploratory capacity, $C$. penicillata is capable of adapting to changes in its environment and may occupy urban environments (Stevenson \& Rylands, 1988).

In many species, home range size is influenced by body size, metabolic needs, social organization, population density and habitat productivity (Dawson, 1979; Harestad \& Bunnell 1979; MacNab 1963; Miranda \& Faria, 2001; Rylands, 1986; Scanlon et al. 1989; Stevenson \& Rylands, 1988). Variation in the size of the home range of the genus Callithrix is from 0.5 to 35.5 ha (Castro, 2003) and for C. penicillata from 2.0 to 18.5 ha (Fonseca et al., 1980; Ruiz-Miranda et al., 2006,) in Cerrado and Atlantic forest, respectively. In urban areas Duarte et al. (2010) found a home-range of 13.1 ha for the same species. Population density of groups depends on resource density in the home range of each group (Stevenson \& Rylands, 1988).

C. penicillata has a diverse diet (Vivo, 1991), which enables this species to live in small home ranges and allows it to adapt to impacted environments (Faria, 1986). C. jacchus and C. penicillata are mentioned by Stevenson \& Rylands (1988) as ecologically the most successful primate species in Brazil, due to their wide geographic distribution, high population densities and their efficiency of habitat exploration, making them capable of living in unfavourable and seasonal habitats (Miranda \& Faria, 2001).

C. penicillata is considered a territorial species, which lives in social groups of 3-15 animals (comprised of a reproductive pair, sub-adults, juveniles and infants) (Stevenson \& Rylands, 1988). Observations made in captivity and in the field of species from the genus Callithrix demonstrate an activity pattern with durations of 10 to 12 hours per day (Sussman \& Kinzey, 1984; Stevenson \& Rylands, 1988). During the day, time is divided into activities, such as travelling, self-grooming, resting, social behaviour (e.g. play, grooming), vocalization and feeding (Stevenson \& Poole, 1976). These daily activities vary according to the hour of the day (Varella \& Yamamoto, 1991). Food is considered a powerful regulator of animal activity (Apelgren et al., 1985) and, obviously, its availability and distribution influences foraging behaviour (Garber, 1988).

The objectives of this study were (1) to investigate the behavioural activity of four groups of $C$. penicillata living in an urban environment and compare their behavioural ecology to animals living in natural habitats; (2) to evaluate the importance of (estimated) food availability in an urban area in relation to home range size, group size and population density.

\section{Material and Methods}

This study was carried out in the grounds of the Belo Horizonte Zoological garden, Minas Gerais, Brazil (19 $\left.51^{\prime} \mathrm{S}, 44^{\circ} 00^{\prime} \mathrm{W}\right)$. The climate in the area was mild throughout the year with a rainy season between October and March, and an annual mean temperature of about $23^{\circ} \mathrm{C}$. The zoo is bordered by a residential region and internally it has an area of 1,460 hectares (ha) of which $70 \%$ is a nature reserve (characterized as mainly Cerrado - more specifically semi deciduous woodland - Cerradão)

Four groups were studied. The smallest group of $C$. penicillata consisted of four individuals. The largest group consisted of thirteen individuals. However, there was daily variation in these numbers. Over the period of the study, a mean of these numbers was used. Four study groups were chosen using the criterion that there was no apparently physical contact between these groups (it was not possible to fully eliminate the possibility of vocal interactions). In this way, the behaviour of one group probably did not influence another group; however, in some cases a nonstudy group interacted with two or more of our study groups. Therefore, we considered our study groups to be statistically independent units. Furthermore, all groups contained only one reproductive female, an adult male and a minimum of two juveniles (group 
sizes ranged from a minimum of four to a maximum of thirteen individuals during the study).

To accurately represent the number of animals in our groups we counted the number of animals during each observation session, this was because a pilot study had revealed that group size varied due to births, deaths, emigrations and individuals becoming temporarily separated from their groups. Furthermore, it was decided that as our groups were, normally, spatially cohesive units, the behaviour of the group would be considered and not the individuals in the group. Our rationale was to reduce the risk of type I statistical errors (Zar, 1998) due to artificially inflated sample sizes, which result from counting individuals in the same group as statistically independent units (i.e. pooling fallacy). As our groups were always found in the same area, due to their territorial behaviour, it was not necessary to mark individuals (Castro, 2003) and their natural individual markings made it possible to confirm the identity of group members.

Data was collected from April to October/2005. Observation sessions of the groups were done three times a week during the day, totalling 84 hours of observation, 21 ( \pm 1.16) hours (mean \pm S.D.) for each group (representing a total of 19,343 different sample points for all four groups). Behavioural data were collected using scan sampling of all visible group members (dependent infants were not included) with instantaneous recording of behaviour every 90 seconds (Martin \& Bateson, 1993). To be valid, a scan sample had to have a minimum of eight sample points. Recorded behaviours are shown in Tab. I. To determine group size, the mean minimum number of individuals was calculated for each group during each scan.

To estimate groups' home range sizes a minimum of two geographical points were collected using a GPS device (Garmin, USA, model GPS III Plus), during each observation session. It should be noted that due to the presence of animal enclosures it was not possible to systematically collect geographical fixes (therefore analyses such as Kernel were not possible). At our university's GIS Laboratory (CEPIGAR), the collected points were used to project the home range of each group, using the minimum convex polygon method, and calculate its area, using ArcGIS software (Environmental Systems Research Institute - ESRI - California, USA,). From the collected points, for each group's home range, the two most distant points and were selected the distance between them measured; this distance was used to calculate the area of influence around each home range (an arc being drawn from the geographical centre of the home range using half this distance). The calculation of this area of influence was made using Autocad map software (Autodesk firm, California, USA).

To characterize the land-use and vegetation cover of each group's home range aerial photographs were interpreted (using the programs Autocadmap, ArcGIS, Google Earth and GPS Track Maker) so as to calculate the percentage of green area (i.e. natural vegetation), clearings and built area (i.e. asphalt, concrete, constructions) (Figure 1). The quantity of food plants in the green areas, for our study species within their home ranges, was estimated by the zoo's botanist at the start and the end of our study who ranked ( 1 to 4 with 1 being the highest) the areas in terms of estimated natural food availability in relation to a wild marmoset's diet.

The marmosets were frequently observed feeding in the enclosures of some species of birds in the zoo. Although not directly offered to the marmosets, the birds' food represented a part of the marmosets' diet (personal observation). These resources were considered as extra food for the marmosets. The amount of extra food available was estimated by considering which enclosures small primates could enter, type and quantity of available food. From this data the groups' home ranges were ranked from the one with the most (designated number 1 in the rank) to the one with least (designated number 4 in the rank) extra food available.

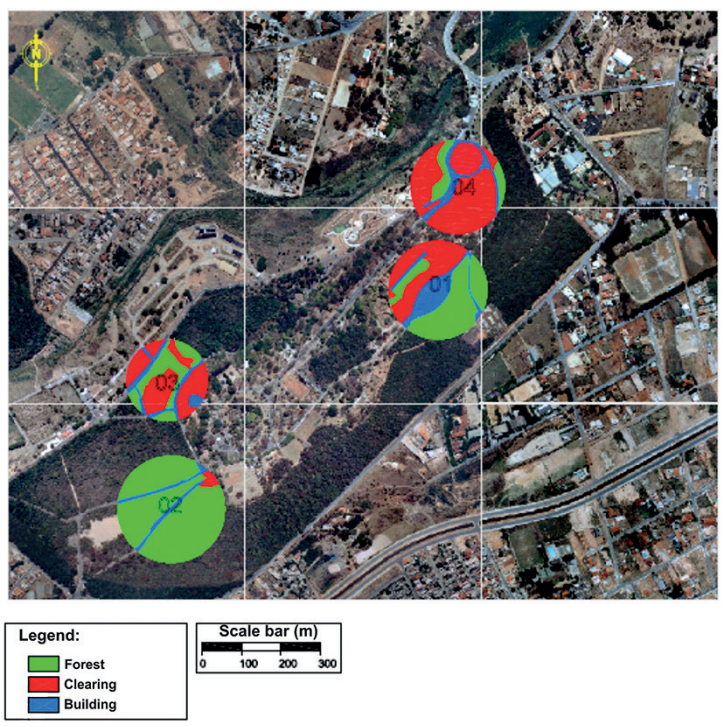

Figure 1: Characterization of C. Penicillata home-range in the Belo Horizonte Zoo, Minas Gerais, Brazil. 
Table 1. Behavioral activities recorded from four groups of marmosets (C.penicillata) living in zoo in Belo Horizonte

\begin{tabular}{lc}
\hline Behaviour & Description \\
\hline Resting & Individual awake but not moving or engaged in any activity. \\
\hline Inactive alert & Individual in a stationary position but attentive to its surroundings. \\
\hline Travelling behaviour & Individual moving, running, jumping or walking. \\
\hline Positive social behaviour & Non-aggressive interactions between individuals (e.g. playing or grooming). \\
\hline Negative social behaviour & Aggressive interactions between individuals, including aggressive \\
\hline Feeding behaviour & Cocalizations. \\
\hline Self-grooming behaviour & Individual picking through own fur with hands and/or mouth. \\
\hline Vocalizing & Any type of non-aggressive vocalization $(e . g$. contact, alarm, stress). \\
\hline Other behaviours & Any behaviours executed by individuals not described above. \\
\hline Not visible & Self explanatory. \\
\hline
\end{tabular}

Table 2. Kruskal-Wallis H-values and mean \pm SEM percentages of time devoted to different behaviours of four groups of marmosets (C.penicillata) living in a zoo in Belo Horizonte

\begin{tabular}{cccccc}
\hline & H & Group 1 & Group 2 & Group 3 & Group 4 \\
\hline $\mathrm{R}$ & $17.65^{* * *}$ & $15.87 \pm 2.49^{\mathrm{a}, \mathrm{b}}$ & $20.93 \pm 2.62^{\mathrm{a}}$ & $22.70 \pm 1.75^{\mathrm{a}}$ & $6.80 \pm 2.13^{\mathrm{b}}$ \\
\hline $\mathrm{I}$ & $28.26^{* * *}$ & $9.28 \pm 2.70^{\mathrm{a}}$ & $8.43 \pm 3.21^{\mathrm{a}}$ & $3.68 \pm 1.05^{\mathrm{a}}$ & $38.39 \pm 3.75^{\mathrm{b}}$ \\
\hline $\mathrm{T}$ & $20.29^{* * *}$ & $14.37 \pm 1.82^{\mathrm{a}}$ & $25.56 \pm 2.00^{\mathrm{b}}$ & $27.39 \pm 1.77^{\mathrm{b}}$ & $22.49 \pm 1.17^{\mathrm{b}}$ \\
\hline $\mathrm{S}+$ & $9.82^{*}$ & $4.43 \pm 1.26^{\mathrm{a}, \mathrm{b}}$ & $6.51 \pm 1.32^{\mathrm{a}}$ & $2.92 \pm 1.01^{\mathrm{a}, \mathrm{b}}$ & $2.48 \pm 1.22^{\mathrm{b}}$ \\
\hline $\mathrm{S}-$ & 6.18 & $0.04 \pm 0.04^{\mathrm{a}}$ & $0.15 \pm 0.08^{\mathrm{a}}$ & $0.35 \pm 0.019^{\mathrm{a}}$ & $0.00 \pm 0.00^{\mathrm{a}}$ \\
\hline $\mathrm{V}$ & 3.41 & $5.35 \pm 1.20^{\mathrm{a}}$ & $4.21 \pm 0.72^{\mathrm{a}}$ & $5.23 \pm 0.87^{\mathrm{a}}$ & $2.42 \pm 0.31^{\mathrm{a}}$ \\
\hline $\mathrm{F}$ & $19.86^{* * *}$ & $8.41 \pm 2.41^{\mathrm{a}, \mathrm{b}}$ & $3.47 \pm 0.65^{\mathrm{a}}$ & $2.82 \pm 0.94^{\mathrm{a}}$ & $12.26 \pm 2.25^{\mathrm{b}}$ \\
\hline $\mathrm{G}$ & $16.85^{* * *}$ & $1.34 \pm 0.26^{\mathrm{b}}$ & $3.66 \pm 0.44^{\mathrm{a}}$ & $2.51 \pm 0.41^{\mathrm{a}, \mathrm{b}, \mathrm{c}}$ & $2.05 \pm 0.27^{\mathrm{b}, \mathrm{c}}$ \\
\hline $\mathrm{O}$ & 4.92 & $0.32 \pm 0.27^{\mathrm{a}}$ & $0.00 \pm 0.00^{\mathrm{a}}$ & $0.07 \pm 0.07^{\mathrm{a}}$ & $0.00 \pm 0.00^{\mathrm{a}}$ \\
\hline $\mathrm{N}$ & $20.52^{* * *}$ & $40.59 \pm 2.45^{\mathrm{a}}$ & $27.08 \pm 2.95^{\mathrm{b}}$ & $32.32 \pm 3.48^{\mathrm{a}}$ & $13.11 \pm 3.18^{\mathrm{c}}$ \\
\hline $\mathrm{Difr}$
\end{tabular}

Different superscript letters indicate statistically significant differences between groups as detected by post-hoc Mann-Whitney U-tests (Note: post-hoc differences are based on median values produced by the Mann-Whitney U-tests with p-values corrected by the Bonferroni method for multiple comparisons).

$\mathrm{H}=$ Kruskal-Wallis statistic $(\mathrm{DF}=3$ in all cases); $*=\mathrm{p}<0.05 ; * * *=\mathrm{p}<0.001 ; \mathrm{R}=$ Resting; $\mathrm{I}=$ Inactive alert; $\mathrm{T}=$ Travelling behaviour; $\mathrm{S}+$ = Social positive behaviour; $\mathrm{S}-$ = Social negative behaviour; $\mathrm{V}=$ Vocalizing; $\mathrm{F}=$ Feeding behaviour; $\mathrm{G}=$ Selfgrooming; $\mathrm{O}=$ Other behaviours; $\mathrm{N}=$ Not visible.

Visitors to the zoo, more specifically those who passed inside the boundaries of our groups' home ranges, were affecting behaviour and diet: as visitors were frequently observed interacting with and feeding the marmosets (personal observation). The number of visitors passing through home ranges was counted (two eight hour sessions per area) to determine the level (rank) of human contact with each group. The groups with most visitor contact, probably, received most extra food.

As previously mentioned, the data collection was organized so that each group could be considered an independent statistical unit. The Anderson-Darling statistical test confirmed that behavioural data, for group comparisons, did not meet the requirements for parametric statistics; 
therefore, non-parametric statistics were used for these comparisons (i.e. Kruskal-Wallis and MannWhitney U-test). The data for correlations was tested for the requirements for parametric statistics and the two variables inactive alert and group density did not meet the requirements for parametric statistics. However, after a square-root transformation inactive alert met the requirements, it proved impossible to transform group density to meet these requirements and so this variable was not analyzed.

Behavioural data for all groups (per observation session) was converted into proportions before any data analysis was conducted. In order to determine if groups presented statistical differences in behaviours expressed by groups, the Kruskal-Wallis test was used. When a significant difference was detected we performed post-hoc Mann-Whitney U-tests between pairs of groups with p-values corrected by the Bonferroni method for multiple comparisons (Sheskin, 2004).

The Mann-Whitney U-test was used to detect significant differences between the data from this study and results published in literature that related to home range size, group size and population density. Pearson correlations were made to determine if there were correlations between recorded ecological variables (i.e. food availability, home-range, etc) and behaviours that were recorded in the study.

\section{Results}

Groups of C. penicillata living in the Belo Horizonte Zoo spent a considerable percentage of their time travelling $(22.45 \pm 2.88)$; resting (16.58 \pm $3.57)$, inactive alert $(14.95 \pm 7.91)$ and feeding (6.74 \pm 2.22 ) (mean $\% \pm$ SEM). All other behavioural activities were expressed for less than $5 \%$ of their activity repertoire (Tab. II).

To summarize inter-group comparisons for behavioural activities (for full details see Tab. II): Group 4 devoted the smallest amount of time to resting and the most time inactive alert. This was also the group that spent the most time feeding and was the most visible of the groups. Group 2 spent the largest amount of time in social positive and self-grooming behaviour. Group 1 devoted the least amount of time to travelling. The four groups of $C$. penicillata did not present significant differences for negative social behaviours, vocalizing or 'other' behaviours (see Tab. II).
The home range size of each group of $C$. penicillata, as well as its area of influence, group size and population density, are presented in Tab. III. Results from other studies concerning home range size, group size and density of groups of $C$. penicillata and type of habitat of each home range studied are shown in Tab. IV for comparative purposes.

Estimated natural food availability (Tab. V) showed significant negative correlations with resting and social negative behaviour (resting: $\mathrm{r}=-0.955$; $\mathrm{N}=4 ; \mathrm{p}<0.05$; social negative: $\mathrm{r}=-0.955 ; \mathrm{N}=4$ $\mathrm{p}<0.05)$ and a significant positive correlation with feeding $(r=0.966 ; \mathrm{N}=4 ; \mathrm{p}<0.05)$. The percentage of green area had a significant positive correlation with positive social behaviour $(\mathrm{r}=0.989 ; \mathrm{N}=4 ; \mathrm{p}$ $<0.05$; Tab. VI); whereas the percentage of clearing had a significant negative correlation with positive social behaviour $(\mathrm{r}=-0.977 ; \mathrm{N}=4 ; \mathrm{p}<0.05$; Tab. VI). The percentage of built area showed a significant negative correlation with self-grooming behaviour $(r=-0.965 ; \mathrm{N}=4 ; \mathrm{p}<0.05 ;$ Tab. VI). Finally, the mean group size had a significant positive correlation with resting $(\mathrm{r}=0.953 ; \mathrm{N}=4 ; \mathrm{p}<0.05)$ and a significant negative correlation with feeding behaviour $(\mathrm{r}=-0.978 ; \mathrm{N}=4 ; \mathrm{p}<0.05)$.

Comparing home range sizes $\left(\mathrm{W}=19.0 ; \mathrm{N}_{1}\right.$ $=4 ; \mathrm{N}_{2}=7 ; \mathrm{p}=0.395$, Tab. III and IV), group sizes $\left(\mathrm{W}=19.0 ; \mathrm{N}_{1}=4 ; \mathrm{N}_{2}=6 ; \mathrm{p}=0.594\right.$, Tab. III and IV) and population density $\left(\mathrm{W}=27.0 ; \mathrm{N}_{1}=4, \mathrm{~N}_{2}=\right.$ $6 ; \mathrm{p}=0.240 ;$ Tab. III and IV) with published studies showed no significant differences.

\section{Discussion}

The results showed that home range size, group size and population density of groups of $C$. penicillata living wild in the Belo Horizonte Zoo were within expected values for this species in natural and urban habitats (Faria, 1989; Fonseca et al., 1980; Fonseca \& Lacher, 1984; Miranda \& Faria, 2001; Ruiz-Miranda et al., 2006; Duarte et al., 2011). These aspects seemed to be, likewise for wild conspecifics, influenced by aspects of their home range (principally the occurrence of food resources in their environment).

Only Group 3 had a value smaller than the published home range size (Tab. III and IV). While this group did not have an extensive green area (Tab. VI), it did have the highest amount of estimated natural food available (Tab. V) due to the presence of an organic waste dump that provided nutrients for 
Table 3. Home range size, area of influence, group size and group density from four groups of marmosets (C.penicillata) living in a zoo in Belo Horizonte.

\begin{tabular}{lcccc}
\hline Group & $\begin{array}{c}\text { Home range size } \\
(\mathbf{h a})\end{array}$ & $\begin{array}{c}\text { Area of influence } \\
(\mathbf{h a})\end{array}$ & $\begin{array}{c}\text { Group size* } \\
(\text { mean } \pm \text { SEM) }\end{array}$ & $\begin{array}{c}\text { Group density (indiv./ } \\
\text { ha) })\end{array}$ \\
\hline $\mathrm{G} 1$ & 3.04 & 4.90 & $5.2 \pm 0.43$ & 1.71 \\
\hline $\mathrm{G} 2$ & 4.12 & 5.81 & $7.0 \pm 0.41$ & 1.70 \\
\hline $\mathrm{G} 3$ & 1.72 & 3.33 & $6.5 \pm 0.44$ & 3.78 \\
\hline G4 & 2.55 & 4.47 & $4.0 \pm 0.00$ & 1.57 \\
\hline Mean & 2.85 & 4.62 & $5.7 \pm 0.67$ & 2.19 \\
\hline
\end{tabular}

* Mean minimum group size observed; ha = hectare; indiv. /ha = individuals per hectare.

Table 4. Published home range sizes, group sizes, group densities and habitat types of C. penicillata groups and mean of present study.

\begin{tabular}{lccccc}
\hline Reference & $\begin{array}{c}\text { Home } \\
\text { range }(\mathbf{h a})\end{array}$ & $\begin{array}{c}\text { Group } \\
\text { size }\end{array}$ & $\begin{array}{c}\text { No. of } \\
\text { groups }\end{array}$ & $\begin{array}{c}\text { Group density } \\
\text { (indiv./ha) }\end{array}$ & Habitat \\
\hline Mean of present study & 2.85 & 5.70 & 4 & 2.19 & Semi-Urban \\
\hline FonsecA et al. (1980) & 2.00 & 5.00 & 1 & 2.00 & Cerrado \\
\hline Fonseca \& Lacher (1984) & 2.50 & 4.50 & 1 & 1.80 & Cerrado \\
\hline Faria (1989) & 3.50 & - & - & - & Cerrado \\
\hline Miranda \& Faria (2001) & 8.25 & 4.67 & 1 & 0.57 & Cerrado* \\
& 18.50 & 7.33 & 1 & 0.40 & Cerrado* \\
& 12.00 & 9.83 & 1 & 0.83 & Cerrado* \\
\hline Ruiz-MiRANDA et al. (2006) & 2.88 & 9.00 & 1 & 0.32 & Forest** \\
\hline
\end{tabular}

- = data not available; $*$ = semi-urban cerrado; $* *=$ Atlantic forest; ha = hectare; indiv. $/$ ha $=$ individuals per hectare

surrounding plants and trees. Thus, Group 3, despite having a relatively large mean group size, was able to live in a small home range due to high estimated natural food availability. In the study, Group 2 had the largest home range, which probably reflects the fact that it had the largest mean group size and a low occurrence of food resources (Tab. III and V, Miranda \& Faria, 2001; Rylands, 1986; Scanlon et al., 1989). However, it should be pointed out that there exists a deficiency in the published literature in that most home range data are based on only one group (Tab. IV). The area of influence values showed the same effect as home range size, except that their values were consistently higher than those reported in Tab. IV, except for marmosets in a semi-urban Cerrado habitat (Miranda \& Faria, 2001).

Positive social behaviour decreased with increasing amounts of clearings; whereas self-grooming behaviour decreased with increasing amounts of built area. Taken together, these results suggest that the animals may have been more 'relaxed' in natural vegetation as this provided cover from predators (Stevenson \& Rylands, 1988).

While mean group size in this study was within published limits (Tab. III and IV) it did vary during the study; this was due to two principal factors: disappearance of individuals and separation of individuals. During the study it was noted that many dependent infants disappeared; for example, in Group 2 three dependent infants disappeared. The other main factor affecting group size was the temporal separation of individuals from the main group. This factor principally affected sub-adults who, when observed, seemed to be approaching other groups, perhaps with the objective of attracting a mate (Stevenson \& Rylands, 1988). Group 4 had a group size smaller than that recorded in the literature ( 4 individuals, Tab. III), and this may reflect 
Behavioural and ecological aspects of black tufted-ear marmosets

Table 5. Ranking (from high (1) to low (4)) of estimated natural food availability, extra food availability and quantity of visitors in the home ranges of each group.

\begin{tabular}{lccc}
\hline & $\begin{array}{c}\text { Estimated natural food } \\
\text { availability }\end{array}$ & Extra food availability & Visitors/hour \\
\hline Group 1 & 3 & 1 & 2 \\
\hline Group 2 & 2 & 3.5 & 1 \\
\hline Group 3 & 1 & 2 & 4 \\
\hline Group 4 & 4 & 3.5 & 3 \\
\hline
\end{tabular}

Table 6. Percentages of green areas, clearings and built areas in each group's area of influence.

\begin{tabular}{lccc}
\hline & Green area & Glearings & Built area \\
\hline Group 1 & $46(2.25)$ & $32(1.57)$ & $22(1.08)$ \\
\hline Group 2 & $90(5.23)$ & $8(0.46)$ & $2(0.12)$ \\
\hline Group 3 & $29(0.97)$ & $55(1.83)$ & $16(0.53)$ \\
\hline Group 4 & $11(0.49)$ & $74(3.31)$ & $15(0.67)$ \\
\hline Mean & $44(2.03)$ & $42(1.94)$ & $14(0.65)$ \\
\hline
\end{tabular}

Values in brackets are in hectares.

its small quantity of green area (only 11\%; Tab. VI) and, consequently, estimated natural and extra food. Interestingly, no infants were observed in this group, and its group size did not vary during our study.

In terms of behaviour, mean group size was positively associated with resting and negatively associated with feeding behaviour. The increase in resting behaviour probably reflects the increased security that a larger group has against predators; whereas the decrease in feeding time may reflect increase in competition for food resources (Stevenson \& Rylands, 1988).

The mean group density in this study did not differ from that of studies in the Cerrado (Fonseca et al. 1980, Fonseca \& Lacher 1984) with insufficient comparative data being available for the Atlantic forest (Tab. IV). However, Group 3 showed a higher density than that of any published study (Tab. III); this was due to an exceptionally high occurrence of food resources in its home range because of the aforementioned organic waste dump. Thus, demonstrating that $C$. penicillata can live in higher densities than those that occur naturally. It could be argued that the density of marmosets in this study was even higher as their green area (i.e. natural habitat) only had a mean of $44 \%$ (Tab. VI). Therefore, it may be justifiable to double the densities found in this study (or halve the home range values); however, it was decided to use gross density (individuals/total area) and not net density (individuals/green area) because marmosets were observed using all three types of land-use and vegetation cover. In a study in a semi-urban Cerrado, habitat population density was increased by the extra food made available from homes (Miranda \& Faria, 2001).

Due to lack of published data and methodological differences between the present and published studies, it was not possible to do statistical comparisons for behavioural activity repertoires. In general, data from the study followed that of other published studies with the travelling, resting, inactive alert and feeding behaviours being most expressed (Stevenson \& Rylands, 1988). However, the percentages of time devoted to these activities were lower in this study; this was not due to these marmosets expressing behaviours not seen in other studies. Another possible explanation is that behavioural comparisons between studies are difficult due to environmental differences in food availability. The animals involved in this study probably had more food available than that of wild groups, which might have reduced traveling time and increased resting time. Published data indicate that $C$. penicillata devote between 34 to $45 \%$ of their time travelling (Miranda \& Faria, 2001) compared to the $22 \%$ found in this study. Data on C. jacchus indicate that they devote 


\section{Marina Nogueira dos Santos et al}

up to $53 \%$ of their time to resting (see Stevenson \& Rylands, 1988, for a review of published data) and $12 \%$ to feeding compared to the 16.5 and $6.7 \%$ in this study. Thus, resting time in this study was not higher than that reported in published studies. The amount of time not visible varied significantly between groups (Tab. II); this effect had the potential to bias our observations. However, in all of these cases the animals involved in this study were hidden in dense foliage and were not moving. Stevenson and Rylands (1988) noted that marmosets normally rest in dense vegetation, where they are difficult to observe: we therefore suspect in these cases that the marmosets were resting. Furthermore, inactive alert was recorded as a separate behaviour from resting in this study, while in other studies the definition of resting also includes this behaviour (Stevenson \& Rylands, 1988). If the resting time in this study was summed with not visible time and inactive alert to create another measure of resting behaviour, then this data would have indicated that the marmosets in this study were indeed resting more than those in other published studies $(59.8 \%$ of the time, Tab. II). Interestingly, Group 4 who had the smallest amount of natural vegetation (Tab. VI) and, consequently, little foliage to hide behind was the most inactive alert group and the most visible of the groups (Tab. II). It also had a high feeding time, which may reflect its greater levels of activity (Garber et al., 1988).

Group 2, with greatest number of individuals (Tab. III), presented the highest rate of positive social behaviour and self-grooming (Tab. II). Studies show that group size and composition (presence of juveniles) are often directly related to the expression of social behaviours, such as play (Stevenson \& Poole, 1976; Voland, 1977) and grooming (Stevenson \& Rylands, 1988; Yamamoto, 1991).

It is interesting to note that, in this study, negative social behaviour was extremely rare (Tab. II): we suspect this reflects the relatively high occurrence of food resources in their environment and, consequently, low levels of intra-group competition.

The correlations showed what was expected, this being that the availability of estimated natural food in a group's home range was positively associated with feeding, and negatively associated with resting and negative social behaviour. Food availability can directly affect activity patterns of a primate group, as it influences hunger and consequently traveling behaviour (Apelgren et al., 1985; Garber, 1988; Maier et al., 1982; Rylands, 1981, 1986; Stevenson \& Rylands, 1988). As expected, animals fed more when estimated natural food was more abundant; the lower level of negative social behaviour in this situation may reflect reduced competition for food resources (Stevenson \& Rylands, 1988). As both group size and food availability varied in a non-systematic manner, it is not possible to comment on the effect of food availability on group size (Tab. III and V).

\section{Conclusion}

The data presented in this paper showed that the behaviour and ecology of semi-urban marmosets were similar to that of their wild-living counterparts and, surprisingly, that they were able to survive in areas with little natural vegetation due to their use of alternative food sources.

\section{References}

Apelgren, K. N., Frim, D. M., Harling-Berg, C. J., Gander, P. H., \& M.C. Moore-Ede. (1985). Effectiveness on cyclic intragastric feeding as a circadian Zeitgeber in the squirrel monkey. Physiology \& Behaviour, 34, 335340 .

Box, H. O. (1991). Responsiveness to environmental change: interrelationships among parameters p. 57-74. In H. O. Box (Ed.), Primate Responses to Environmental Change. London, Chapman and Hall.

Castro, C. S. S. (2003). Tamanho da área de vida e padrão de uso do espaço em grupos de sagüis, Callithrix jacchus (Linnaeus) (Primates, Callitrichidae). Revista Brasileira de Zoologia, 20, 91-96.

Dawson, G. A. (1979). The use of the time and space by the Panamanian tamarins, Saguinus oedipus. Folia Primatologica, 39, 253-284.

Duarte, M. H. L. (2010). Vizinhos barulhentos: vamos mudar de casa? O caso do mico-estrela. Dissertação de Mestrado, Programa de Pós-graduação e Zoologia dos Vertebrados, Pontifícia Universidade de Minas Gerais, Brasil.

Duarte, M .H. L., Vecci, M. A., Hirsch, A., \& Young, R. J. (2011). Noisy human neighbours affect where urban monkeys live. Biology letters, 7, 849-842. 
Faria, D. S. (1986). Tamanho, composição de um grupo social e a área de vivência (home range) do sagüi Callithrix jacchus penicillata na mata ciliar do córrego Capetinga, Brasília, DF p. 87-105. In M.T. Mello (Ed.). A Primatologia no Brasil 2. Brasilia, Sociedade Brasileira de Primatologia.

Faria, D. S. (1989). O estudo de campo com mico estrela no Planalto Central Brasileiro p. 109-121. In C. Ades (Ed.). Etologia de animais e de homens. São Paulo, USP.

Fonseca, G. A. B., Lacher, T. E. Jr., Alves C. Jr., \& Magalhães-Castro, B. (1980). Some ecological aspects of free-living black tufted-ear marmosets (Callithrix jacchus penicillata). Antropologia Contemporâneo, 3, 197.

Fonseca, G. A. B., \& Lacher, T. E. Jr. (1984). Exudatefeeding by Callithrix jacchus penicillata in semideciduous woodland (cerradão) in Central Brazil. Primates, 25, 441-450.

Garber, P. A. (1988). Foraging decisions during nectar feeding by tamarin monkeys (Saguinus mystax and Saguinus fuscicollis, Callitrichidae, Primates) in Amazonian Peru. Biotropica, 20, 100-106.

Harestad, A. S., \& Bunnell, F. L. (1979). Home range and body weight - a reevaluation. Ecology, 60, 389-402.

Leite, G. C., Duarte, M. H. L., \& Young R. J. (2011). Human-marmoset interactions in a city park. Applied Animal Behaviour Science ,132, 187 - 192.

MacNab, B. K. (1963). Bioenergetics and the determination of home range size. American Naturalist, 97, 133-140.

Maier, W., Alonso, C., \& Langguth, A. (1982). Field observations on Callithrix jacchus jacchus. Zeitschrift fur Säugetierkunde, 47, 334-346.

Martin, P., \& Bateson, P. (1993). Measuring behaviour: an introductory guide. Cambridge, MA: University Press.

Miranda, G. H. B., \& Faria. D. S. (2001). Ecological aspects of black-pincelled marmosets (Callithrix penicillata) in the cerradão and dense cerrado of the Brazilian Central Plateau. Brazilian Journal of Biology, 61, 397-404.

Ruiz-Miranda, C. R., Affonso, A. G., Morais, M. M., Verona, C. E., Martins, A., \& Beck B. 2006.
Behavioral and ecological interactions between reintroduced golden lion tamarins (Leontopithecus rosalia Linneaus, 1766) and introduced marmosets (Callithrix spp., Linneaus, 1758) in Brazilian Atlantic Coast Forest fragments. Brazilian Archives of Biology and Technology, 49, 99-109.

Rylands, A. B. (1981). Preliminary field observations on the marmosets Callithrix humeralifer intermedius (Hershkovitz, 1977) at Dardanelos, Rio Aripuanã, Mato Grosso. Primates, 22, 46-59.

Rylands, A. B. (1986). Ranging behaviour and habitat preference of a wild marmoset group, Callithrix humeralifer (Callitrichidae-Primates). Journal of Zoology, 210, 1-26.

Sabbatini, G., Stammati, M., Tavares, M. G. H., Giuliani, M. V. \& Visalberghi, E. (2006). Interactions between humans and capuchin monkeys (Cebus libidinosus) in the Parque Nacional de Brasília, Brazil. Applied Animal Behaviour Science, 97, 272-283.

Scanlon, C. E., Chalmers, N. R. \& Monteiro da Cruz, M. A. O. (1989). Changes in the size, composition and reproductive condition of wild marmoset groups (Callithrix jacchus jacchus) in northeast Brazil. Primates, 29, 295-305.

Sheskin, D. J. (2004). Handbook of parametric and nonparametric statistical procedures (Third Edition). Boca Raton: Chapman \& Hall/CRC.

Stevenson, M. F., \& Poole, T. B. (1976). An ethogram of the common marmoset, Callithrix jacchus jacchus: general behaviour repertoire. Animal Behaviour, 24, 428-451.

Stevenson, M. F., \& Rylands, A. B. (1988). The marmosets, genus Callithrix p. 131-222. In Mittermeier, R. A., Rylands, A. B., Coimbra-Filho, A., \& Fonseca, G. A. B. (Eds.). Ecology and Behaviour of Neotropical Primates. Contagem, Brazil, Littera Maciel.

Sussman, R. W., \& Kinzey, W. G. (1984). The ecological role of the Callitrichidae: A review. American Journal of Physical Anthropology, 64, 419-449.

Varella, V. S., \& Yamamoto M. E. (1991). Influência da disponibilidade de alimento sobre o comportamento exploratório de primatas p. 57-61. In Rylands A. B., \& Bernades, A. T. (Eds.). A Primatologia no Brasil 3. Belo Horizonte, Fundação Biodiversitas. 


\section{Marina Nogueira dos Santos et al}

Vivo, M. (1991). Taxonomia de Callithrix Erxleben, 1777 (Callitrichidae, Primates). Fundação Biodiversitas, Belo Horizonte, Brasil.

Voland, E. (1977). Social play behaviour of the common marmoset (Callithrix jacchus Erxl., 1977) in captivity. Primates, 18, 883-902.
Yamamoto, M. E. (1991). Comportamento social do gênero Callithrix em cativeiro p. 63-81. In Rylands, A. B., \& Bernades, A. T. (Eds.). A Primatologia no Brasil 3. Belo Horizonte, Fundação Biodiversitas.

Zar, J. H. (1998). Biostatistical Analysis. New Jersey: Prentice Hall. 